\title{
Lumen
}

Selected Proceedings from the Canadian Society for Eighteenth-Century Studies

\section{Locke, Religion, Rights, and the Rise of Modernity}

\section{Kim Ian Parker}

Volume 31, 2012

URI : https://id.erudit.org/iderudit/1013071ar

DOI : https://doi.org/10.7202/1013071ar

Aller au sommaire du numéro

Éditeur(s)

Canadian Society for Eighteenth-Century Studies / Société canadienne d'étude du dix-huitième siècle

ISSN

1209-3696 (imprimé)

1927-8284 (numérique)

Découvrir la revue

Citer cet article

Parker, K. I. (2012). Locke, Religion, Rights, and the Rise of Modernity. Lumen,

31, 115-129. https://doi.org/10.7202/1013071ar d'utilisation que vous pouvez consulter en ligne.

https://apropos.erudit.org/fr/usagers/politique-dutilisation/ 


\section{Locke, Religion, Rights, and the Rise of Modernity}

KIM IAN PARKER

Memorial University of Newfoundland

"We hold these truths to be self-evident, that all men are created equal, that they are endowed by their Creator with certain unalienable Rights, that among these are Life, Liberty and the pursuit of Happiness" - so runs the beginning of the second paragraph of the American Declaration of Independence. If we ignore, for the moment, the "selfevident" problems of non-inclusive language or the fact that a society which paid lip-service to equal rights was propped up by a system of racial exploitation and slavery, Thomas Jefferson, the architect behind most of the Declaration, was making a point that many modern western democracies, at least in principle, still hold to be true: while government may be an artificial product of human creation, human rights are "unalienable." In this sense, rights are more fundamental than government, for they precede it and are the end towards which government is directed. This raises the question of where does our concept of "unalienable" rights originate? What I want to pursue here is the notion that there is connection between the idea that human beings have certain unalienable rights, and the idea that the Creator endows humans with these rights.

To proceed with this task, I want to take an indirect look at the theologico-political underpinnings of the Declaration. It is well known that Jefferson drew much of his theoretical scaffolding for the Declaration from the English political philosopher John Locke (16321704) and his Two Treatises of Government, especially the Second 
Treatise. ${ }^{1}$ For instance, the idea that "all men are created equal" or that government "derives its just power from the consent of the governed" can be traced to the Second Treatise, sections 54 and 99 respectively. What is perhaps not as well known is that Locke's First Treatise contains a prolonged biblical argument with Sir Robert Filmer (1588-1653), a staunch advocate of the theory of the divine right of kings. Locke's First Treatise is not often read these days, mainly because few are interested in the kind of polemical style that characterizes it, and even fewer are interested in the subject matter - an argument over the proper interpretation of Genesis. One also wonders why a philosopher of the magnitude of John Locke would even bother to trouble himself to expose the absurdities of Filmer's biblical politics. Nevertheless, by hearkening back to Filmer's argument, we can see why Locke's First Treatise was so necessary, how it provides the theological framework for his political system in his Second Treatise, and how it can be said to found a system where rights are deemed "unalienable."

Filmer's "biblical politics" are contained in a number of his writings ${ }^{2}$ though it is Patriarcha, republished in 1680 , which seems to have provoked Locke to respond in kind with his own notion of a "politics from Scripture." Filmer looked to Genesis to "prove" that God gave

1. See, for instance, Louis Hartz, The Liberal Tradition in America (New York: Harcourt Brace, 1955), who writes that "Locke dominates American political thought as no thinker anywhere dominates the political thought of a nation" (140), and Carl Becker's idea in The Declaration of Independence: A Study in the History of Political Ideas (New York: Random House, 1958) that "Jefferson copied Locke" (79). This view has been challenged by Garry Willis in Inventing America: Jefferson's Declaration of Independence (New York: Doubleday, 1978), and by J. G. A. Pocock in Virtue, Commerce, and History (Cambridge: CUP, 1985), but I am more inclined to agree with Garrett Ward Sheldon, The Political Philosophy of Thomas Jefferson (Baltimore: Johns Hopkins, 1991), esp. 41-52, who argues that although there is a republican influence on Jefferson (through Aristotle, Cicero, Montesquieu, and Harrington), Locke has a definite and decisive influence on Jefferson in the areas of human nature, the nature of government, and the right of revolution. It is the issue of human nature which is the one which is immediately relevant here.

2. The standard text of Filmer's works is J. P. Sommerville's Patriarcha and Other Writings (Cambridge: CUP, 1991), which supersedes Laslett's edition, Patriarcha and Other Political Works of Sir Robert Filmer (Oxford: Basil Blackwell, 1949). Laslett's edition is still quite useful for students of Locke as the cross references to Filmer in his own edition of Locke's Two Treatises (Cambridge: CUP, 1967) are to the 1949 edition. All further quotations are from the Sommerville edition.

3. The republication of Filmer's Patriarcha occurred during the middle of the Exclusionist Crisis of 1679-81. The Exclusionist Crisis was an attempt by the Earl of 
the first human being, Adam, an unlimited right to property, absolute political power, and dominion over everything - including other people - in the original grant of government. Adam, as father and as absolute monarch of the whole world, ruled by divine right. All individuals were to be subservient to the king in varying degrees within the hierarchical order: (a) women were subject to men; (b) younger brothers were subject to the eldest brother; (c) the eldest brother was subject to the father; (d) the father was subject to the king. In other words, no one was born in freedom. As Filmer writes in Directions for Obedience to Government in Dangerous and Doubtful Times:

Every man that is born is so far from being free-born that by his very birth he becomes a subject to him that begets him. Under which subjection he is always to live unless by immediate appointment from God or by the grant or death of his father he become possessed of that power to which he was subject. ${ }^{4}$

For Filmer, all people were born in subjection to some authority and "where subjection of children is natural, there can be no natural freedom." As Filmer reasoned, a "natural freedom of mankind cannot be supposed without the denial of the creation of Adam." ${ }^{\text {"F }}$ Further, if people were free only insofar as they were not subject to others, people were not equal. Equality occurred only when "there can be no superior power" and, since society was arranged hierarchically, people cannot be equal. If all the people were equal, a new-born infant "hath a like

Shaftesbury (Locke's friend and patron) to pass a law that would exclude any Catholic from succeeding to the throne. It was even rumoured, during this time, that there was a plot to assassinate Charles and to replace him with his Catholic brother, James, and thereby return the country to Roman Catholicism. The result of this "Popish Plot" and the Exclusionist Crisis was to further deepen the divisions of English politics between the Royalist "Tory" party and the Parliamentary "Whig" party. With the republication of Patriacha in 1680, the Royalist Tory party was handed an "irrefutable" ideological defence of the divine right of kings straight from the texts of Sacred Scripture. In Laslett's view, the political theory of Sir Robert Filmer "had become the official exposition of the Royal and Tory view of the basis of governmental power" $(1949,45)$.

4. Filmer, Directions for Obedience to Government in Dangerous and Doubtful Times, 282.

5. Filmer, Anarchy of a Limited or Mixed Monarchy, 142.

6. Filmer, Observations on Aristotle's Politiques Touching Forms of Government, 237. 
interest with the greatest and wisest man in the world." 7 Thus, a political organization that assumed that all men were free and equal made no sense politically and had no justification in the political teachings of Genesis. Since everyone was born in varying degrees of subjection to some authority, everyone was born in varying degrees of inequality. In other words, only the king had unalienable rights and these were absolute.

Filmer's reading of the Bible is interesting in at least two ways. In the first place, his arguments are less idiosyncratic than a number of commentators have imagined them. Filmer draws upon a venerable patriarchal tradition that reached as far back as Augustine and included such notables as Thomas Aquinas, Marsilio of Padua, John Knox, and many others. Filmer's biblical patriarchal politics also included people such as James I of England, John Overall, John Maxwell, and Archbishop James Ussher. ${ }^{8}$ Filmer's version of biblical patriarchalism, extreme though it may be in associating the absolute power of the monarch with an interpretation of the opening chapters of Genesis, is not considerably different from many other political theorists who also assumed that the Bible should form the basis of political discussion. In fact, prior to the eighteenth century, one would be hard pressed to find any political discussion that did not pay some attention to the Bible. In Filmer's time, the fundamental presupposition was that the Bible was the revealed word of God on a whole host of matters, and many political expositors turned to Adam for a paradigm in their discussion of political theory. How to interpret who Adam was, and what kind of political power he had, were the issues at hand; not whether Adam was relevant to political discussion.

In the second place, Filmer's interpretation legitimated difference, and consequently inequality, among human beings. Since humans were born in a divinely-ordained inequality relative to one another, there could be no movement up or down the social and political scale. Rights were all but non-existent; government preceded and superseded individual rights and was decreed by God. The ruler or king, therefore, had absolute power and absolute right which were grounded in God's

7. Filmer, Anarchy, 142.

8. See the comprehensive study by Gordon J. Schochet, Patriarchalism in Political Thought: The Authoritarian Family and Political Speculation and Attitudes Especially in Seventeenth-Century England (Oxford: Basil Blackwell, 1975). 
grant to Adam and extended over the rest of humanity. It was left up to a political theorist of the stature of John Locke to transform the God-given natural right of one to rule over the many, to the idea of God-given natural rights of everyone to choose the government that they thought would best protect their life, liberty, and property.

Near the beginning of the First Treatise of his Two Treatises of Government, Locke sets out to argue against Filmer's system in which "all government is absolute monarchy" and that "no man is born free." "To do so, Locke attacks the scriptural basis of Filmer's position, the notion of "the sovereignty of Adam."10 Locke notes that Filmer's arguments for the sovereignty of Adam are contained throughout a number of his writings and are based on three premises: (1) God's creation of Adam; (2) Adam's dominion over Eve; and (3) Adam's dominion over his children by paternal authority. ${ }^{11}$ In chapters 3 and 4 of the First Treatise, Locke attacks Filmer's first premise by considering the assumption of Adam's title to authority by virtue of his creation, which Locke finds lacking in the scriptural proof that Filmer needs. In chapter 5, Locke discusses Filmer's second premise, that is, Adam's title to authority by the subjection of Eve. In chapter 6, Locke considers Filmer's third premise, that of Adam's title to sovereignty by the right of fatherhood. Having analysed and dismissed (and ridiculed) the three premises upon which Filmer builds his argument, Locke goes further, in chapter 7, and considers how Adam's power is to be conveyed after his death. In so doing, Locke attacks Filmer's doctrine of primogeniture, and considers the question of "property rights" together with "fatherhood rights." The final four chapters, over half of the First Treatise, continues the discussion of the transference of Adam's power. Locke's problem with Filmer's argument, as stated in chapter 8 , is that Filmer does not properly distinguish between a usurpation, a grant, an inheritance, or an election. Locke proposes to deal with all of these in turn but in fact only deals with inheritance in chapter 9, and the question of who is the legitimate heir in chapters

9. John Locke, First Treatise, sec. 3. Hereafter all references to the Two Treatises will appear by treatise and section number $(\mathrm{I}, 3)$. All quotations are from Peter Laslett's 1967 edition. Spelling and italics are faithful to Laslett's edition unless otherwise stated.

10. Locke, I, 11.

11. Locke, I, 14 . 
10 and 11. It is possible that the discussion of usurpations, grants, and elections were part of the lost middle section of the work which Locke mentions in his Preface.

During the whole of this rather long, tedious discussion, Locke is mainly concerned with drawing out the implications of Filmer's position. On the whole, the tone is sarcastic and condescending, often polemical, as befits the pamphlet wars during the Exclusionist Crisis. Locke often takes issue with Filmer's use of Scripture, pointing out that Filmer is taking enormous liberties with the text, or the text as it is understood "from the direct and plain meaning of the Words." ${ }^{2}$ But while Locke may be able to ridicule the interpretation of Scripture of his less able opponent, that does not mean that he is willing to preclude the Bible or Genesis from participating in any sort of political discussion. This is an important point, for Locke has not only to undermine Filmer's position, which is perhaps the more "natural" one (if we agree with Schochet that patriarchalism is the natural social order in seventeenth-century England), but also to undermine the idea that a single individual called Adam has political power. Locke's Adam, while still retaining political force, is quite different from Filmer's Adam.

This last point should not be understated. Adam - or more particularly, what he represents - functions as a founding political icon for both Filmer and Locke. Unlike other consent theorists, such as Thomas Hobbes (1588-1682), who begins his political discussion of the Bible with Abraham, ${ }^{13}$ and is more interested in the political implications of

12. I, 36. Locke's notion of a "plain reading of Scripture" finds its fullest development in the Preface to his Paraphrase and Notes of the Epistles of St. Paul (a modern critical edition has been edited by Arthur Wainwright in two vols., Oxford: Clarendon, 1987). Here Locke sets out a method of reading the letters of Paul that is based on a careful and "close reading" of each letter with an aim to best understand the intentions of the writer. Locke cautions us to try to avoid reading other commentaries or, as he notes in An Essay Concerning Human Understanding (Peter Nidditch, ed. Oxford: OUP, 1975) the "artificial Ignorance and learned Gibberish" of theologians (see book III, section 10, paragraph 9). Locke's aim is to try to approach each letter on its own, and to avoid reading preconceived ideas into the text. By following this procedure Locke hopes (in the spirit of modern historical criticism) to get to the meaning the text may have had to the original audience for whom it was intended.

13. See Henning Graf Reventlow, The Authority of the Bible and the Rise of the Modern World (London: SCM P, 1984), who comments, "Hobbes differs from Filmer in that he begins with Abraham" (210). 
the giving of the law at Sinai, ${ }^{14}$ Locke retains Adam as symbol of political authority for what he reveals about humanity. ${ }^{15}$ Locke's dispute with Filmer does not, therefore, concern whether Adam is important or not but, rather, what exactly were the political implications of Adam's relation to God. But who exactly Adam was, or what he represented is by no means clear in Locke's thought. Even scholars as sensitive to Locke's political theory such as Ian Harris ${ }^{16}$ and Joshua Mitchell cannot agree on Adam's role: Harris maintains that Locke's Adam is an individual whose actions are exclusive to his own person, whereas Mitchell argues that Locke's Adam is representative of humanity. Harris supports his case by arguing that Locke needs to avoid saying that Adam is humanity's representative, as the idea smacks of the Augustinian doctrine of original sin, and would imply that not only is sin inherited, but political power as well. Mitchell, on the other hand, regards Locke's Adam as the collective singular, for only if Adam is humanity's representative can one argue in favour of the universal rights of freedom and equality.

The issue of whether Adam is to be seen as an individual person or a collective representative of humanity is no small matter either Locke's polemic against Filmer concerned the extent to which Adam as a person, or Adam as a representative of humanity, could be guaranteed rights. Both Filmer and Locke, therefore, look to Adam for a

14. See Joshua Mitchell, Not By Reason Alone (Chicago: U of Chicago P, 1993) who writes, "Moses, to whom was owed obedience and to whom was granted the right of interpretation, emerges as the most prominent political figure in Hobbes" (70).

15. This is expressed most clearly by Mitchell: "Because Adam is a crucial figure for Locke, he must address Filmer rather than, say, Hobbes - who also defends the idea of rule by grant from God. Filmer is the real target here; and this because Locke agrees with the formal thesis Filmer advances: that Adam is politically important and that something survived his fall. They differ only with regard to what survived. Although his conclusions are reminiscent of Filmer's, Hobbes does not rely on Adam to articulate his positive theory of governmental covenant. Locke and Filmer are allies of a sort, as well as antagonists. It is to rebuff Filmer while at the same time defend the notion of the political importance of Adam that the First Treatise is written" (1993, 81). See also Laslett who writes, "it was because Sir Robert Filmer had claimed that there was to be found in Revelation [i.e., Genesis] a proof that God had set some men above other men, fathers above sons and men above women, the older above the younger and kings above all others that his doctrine was so dangerous and had to be refuted. It became necessary to show in minute detail, analysing text after text of the Scriptures, that this interpretation was quite wrong" $(1967,92)$.

16. Ian Harris, The Mind of John Locke (Cambridge: CUP, 1994). 
"rights philosophy." Filmer, in giving unlimited rights to the man Adam, weakens the rights of others to a considerable extent. Conversely, Locke, in limiting the man Adam's natural right, allows for others to have more intrinsic rights. As we shall subsequently see, Adam is paradigmatic for Lock's politics, both in the sense of the grant given to him (Genesis 1:28), and the rights which accrue from that grant; but Locke's Adam is radically different from Filmer's Adam. This view can be seen in Locke's famous discussion of property in the Two Treatises, and what I want to discuss in what follows is how the argument on property presupposes Locke's theological debate with Filmer in the First Treatise, and how it continues to reveal his view of rights in the Second Treatise.

Property, for Locke and other seventeenth-century political theorists, is defined as "Life, Liberty, and Estate," a description similar to the "unalienable rights" with which the Creator is said to endow humanity in the Declaration. ${ }^{17}$ Locke begins to outline the relationship between property and rights in the First Treatise. In the first place, humans are the workmanship of an ethical and moral God and are, in some real sense, the sole property of God, and not the property of other human beings. Rulers cannot, therefore, treat their subjects like property - "like so many herds of cattle" - because, ultimately, humans are the property of their Creator. ${ }^{18}$ Indeed, all ownership is ultimately God's, and humans are only given certain allowances to use property to support themselves and their families. ${ }^{19}$ Whatever property rights are claimed by the people, they can extend no further than what God allows. As Locke writes:

Men may be allowed to have propriety in their distinct Portions of the Creatures; yet in respect of God the Maker of Heaven and Earth, who is the sole Lord and Proprietor of the whole World, Mans Propriety in the Creatures is nothing but that Liberty to use them, which God has permitted. ${ }^{20}$

17. Locke defines property as "Life, Liberty, and Estate" in II, 87 and elsewhere. Jefferson's change of Locke's "life, liberty, and estate," to "life, liberty, and the pursuit of happiness" is, according to Sheldon, attributable to an Aristotelian influence, especially the notion that, in the Nicomachian Ethics, Aristotle defines the greatest goal or purpose for humanity as "happiness" (Sheldon, 9, n. 25).

18. Locke, I, 156.

19. Locke, I, 37 .

20. Locke, I, 39 . 
Locke reiterates this claim in his chapter on the state of nature in the Second Treatise:

For Men being all the Workmanship of one Omnipotent, and infinitely wise Maker; All the Servants of one Sovereign Master, sent into the World by his order and about his business, they are his Property, whose Workmanship they are, made to last during his, not one anothers Pleasure. $^{21}$

Locke's account of property and the rights that are attached to it, therefore, rest on proposition that humans are the property of the Creator. This was a proposition that, for Locke, was beyond question. It included a view of God who stood over and above His creation and had absolute power over them. All creation, including humans, were subservient to Him and could not be shown to be free from Him or equal to Him and, by implication, people were to be considered naturally free and equal to each other in the sense that were all part of God's “Workmanship." For Locke, God has not "by any Manifest declaration of his Will set one above another, and confer on him by an evident and clear appointment an undoubted Right to Dominion and Sovereignty."22

Throughout the First Treatise Locke emphasizes the point that God did not give Adam any private dominion over other people, or any private property but, rather, gave Adam a right in common with the rest of humanity. ${ }^{23}$ The blessing in Genesis 1:28 was a grant to everyone, not just Adam. The blessing, as written in the book of Genesis, reads: "God blessed them and said to them, "Be fruitful and multiply, and fill the earth and subdue it; and have dominion over the fish of the seas and over the birds of the air and over every living thing that moves upon the earth" (NRSV). In his detailed analysis of Genesis 1:28 in the First Treatise, Locke translates the Hebrew "אדם" as humanity, the collective singular, rather than "Adam," a proper name. ${ }^{24}$ It is significant, too, that Locke begins his chapter on property in the Second Treatise by arguing that God's grant to "Adam" concerned all humanity, not just one man. He writes:

21. Locke, II, 6 .

22. Locke, II, 4 .

23. Locke, I, 24, 29.

24. See especially Locke, I, 29-31. 
Whether we consider natural Reason, which tells us, that Men, being once born, have a right to their Preservation, and consequently to Meat and Drink, and such other things, as Nature affords for their Subsistence: Or Revelation, which gives us an account of those Grants God made of the World to Adam and to Noah, and his Sons, "tis very clear, that God, as King David says, Psal. CXV. xvj. has given the Earth to the Children of Men, given it to Mankind in common. ${ }^{25}$

If the Creator has given the world and its creatures to humanity in common in order to preserve what is essentially His property, then it is important that humans continue to survive or, in the language of Genesis, continue "to be fruitful, and multiply, and fill the earth." Humans, therefore, have an obligation and duty to preserve themselves. Thus, in the First Treatise, Locke argues that God gives the earth and everything in it to humanity and gives them a natural right of property "to make use of it for the best advantage of Life, and convenience." ${ }^{27}$ In the Second Treatise, he reinforces this claim stating that every one has a right to their own preservation "as Nature affords for their Subsistence."28 Thus, the obligation to preserve oneself by providing for one's existence forms the basis of the natural right's claim to property and, lest this seem too individualistic, there is also a duty incumbent on everyone to provide for everyone else where their own self-preservation does not come into conflict.

For Locke, this means that people can use property as long as their intentions and objectives fall within the range of natural law - that is, Adam can take all that he wants to feed himself and his family, but he cannot withhold property to the extent that he allows starvation to take place. Thus, what Locke calls "the great and primary Blessing of God Almighty" to Adam, that is, to "Be fruitful, and multiply, and replenish the earth," cannot be met by allowing one person the sole right to distribute property arbitrarily. ${ }^{29}$ The fundamental natural right to property, therefore, is not based primarily on labour, as many have argued. Rather, it is based on a prior claim of the great blessing in Genesis (although it does involve labour to some extent). Indeed, in

25. Locke, II, 25.

26. Genesis, 1:28.

27. Locke, I, 26; cf. I, 87 .

28. Locke, II, 25.

29. Locke, I, 33. 
almost all cases, natural rights are limited by the law of nature and by Scripture such that it is more accurate to speak of Locke as advocating a series of obligations rather than individualistic rights, as he is so often taken to have done. These obligations are to be seen in terms of preservation - that is, preservation of God's workmanship and property, rather than the maximization of an individual's pleasure or wealth. Seen in these terms, Locke's ideas of rights are, in fact, more properly said to be concerned with duties than with anything else. Rights are thus derived from the basis of a personal commitment and a personal responsibility to the Creator.

The natural right to subsistence for the preservation of oneself and others thus forms the basis of Locke's discussion on property. It is a claim grounded in natural law, and known through reason and Scripture. Furthermore, because it antedates government, it demarcates the boundaries between those property rights that are independent of any form of political society and those that are contingent upon belonging to a political society, privileging the former over the latter. In this respect, Locke's conception of human rights as prior to government mirrors the idea of the "unalienable rights" which are found in the Declaration. Rights precede government and are the ends to which it is directed. Furthermore, these rights are equally dispersed throughout humanity. In other words, contrary to what Filmer argues, all children, not just the firstborn, have a right to their parent's property for their preservation. More generally, every person, if they are in need, has a right to another's surplus of property. As Locke writes in the First Treatise, "twould always be a Sin in any Man of Estate, to let his Brother perish for want of affording him Relief out of his Plenty." ${ }^{30}$ Locke's understanding of equal natural right with regard to property is important, for it is based both on Scripture and on natural law, and relates both of these to God's intentions. Locke constantly hearkens back to this theological framework to justify his claim to natural rights.

As mentioned earlier, Locke's theory of property does involve a theory of labour, and it is often called a "labour theory of property," or a "labour theory of value." By applying one's labour to the products of nature in the state of nature, Locke argues, one appropriates or lays claim to the natural object, as well as increasing the value of the land

30. Locke, I, 42. 
or the object in question. Because labour places a different value on property, makes it more productive and allows a greater percentage of the human population to benefit, it can also be seen as the fulfilment of the divine blessing to better preserve humanity. Locke writes, "God, when he gave the World in common to all Mankind, commanded Man also to labour, and the penury of his Condition required it of him. God and his Reason commanded him to subdue the Earth, i.e., improve it for the benefit of Life." ${ }^{11}$ Note how the language of Genesis chapter 3 echoes strongly throughout this passage. Although it is true that, for Locke, "Labour, in the Beginning, gave a Right of Property," this does not mean that labour gives an "unalienable" right to surplus property; in fact, one may be required to give up the fruits of one's labour to another who has a more pressing need for it. ${ }^{32}$ The right to property is based on a prior claim of self-preservation and preservation of others based on the Scriptures and natural law. While labour does establish a link between person and property, it does not give one the right to property beyond what one needs for subsistence. ${ }^{33}$ Further, one can only accumulate property to the extent that it does not spoil, and this "spoilage principle" also has its roots in Locke's particular interpretation of Genesis. In other words, if God has given the world in common to human beings, as Locke understands the blessing of Genesis 1:28 to imply, and gives it to them so that they may use it to increase and multiply, then, Locke argues, God wants human beings to use the land that they have, otherwise it will go to waste and spoil. Thus, there is a theological obligation on people to apply their labour to the land that God gives them in order to feed more people, to avoid letting it spoil, and to allow them to better fulfill the great blessing. ${ }^{34}$ Labour, rather than being a morally neutral action is, for Locke, a theological obligation.

The obligation to fulfill the blessing of Genesis 1:28, however, necessarily introduces private possessions. ${ }^{35}$ Many have understood Locke here to be underwriting a "capitalist manifesto" insofar as Locke

31. Locke, II, 32; cf. II, 35 where Locke writes, "God commanded [man] and his Wants forced him to labour."

32. Locke, II, 45 .

33. Locke, II, 31.

34. Locke, II, 32, 35 .

35. Locke, II, 35 . 
seems to fail to make any specific provision against the unlimited accumulation of wealth insofar as God gave the world and its possessions "to the use of the Industrious and Rational." 36 One could read Locke this way, but one would have do so at the expense of ignoring the crucially important theological obligations that Locke lays at the feet of every individual. To ignore these biblical injunctions could indeed place Locke in the camp of those who would seek to protect unlimited wealth but, for Locke, even unfettered accumulation of private possessions (if not used to benefit humanity) is the cause of much anxiety in the state. As he writes in The Reasonableness of Christianity (1695), "Virtue and Prosperity, do not often accompany one another." ${ }^{37}$ And though Locke had no illusions about the greed and avarice of human beings vis à vis the accumulation of property, it is important to see that Locke speaks in terms of divine obligations rather than individual natural rights when he deals with labour and the appropriation of property. In this sense, Locke can distinguish between those who hoard and thereby violate the law of nature, and those who follow the divine imperative by accumulating possessions for the betterment of humanity.

Locke's natural rights are a fulfilment of one's duties to God, and thus Locke is able to draw a connection between what rights a human may have and what the Creator wants one to do. Rights are not what

36. Locke, II, 34. Most famously and probably most subtly argued by C. B. Macpherson in his Political Theory of Possessive Individualism (Oxford: OUP, 1962).

37. See John Locke: Writings on Religion, edited by Victor Nuovo (Oxford: Clarendon, 2002), 202. In an unpublished manuscript entitled "homo ante et post lapsum" (man before and after the Fall), Locke points out that "private possessions and labour which now the curse on the earth had made necessary, by degrees made a distinction of conditions it gave room for covetousness, pride and ambition, which by fashion and example spread the corruption which has so prevailed over mankind" (MS Locke c. 28, f. 113, printed in Locke: Political Writings, edited by Mark Goldie, Cambridge: CUP, 1996, 321). Similarly, in a cryptic passage in the Second Treatise, Locke alludes to a Golden Age "before vain Ambition, and amore sceleratus habendi, evil Concupiscence" (II, 111), had corrupted humanity. While Locke, in these two passages, almost seems to be suggesting that corruption and greed were a result of the Fall, this doctrine seems difficult to reconcile with his statements elsewhere that what humanity lost in the Fall was immortality rather than a kind of wholesale corruption (see especially the Reasonableness of Christianity). What is probably Locke's concern here, however, is that once individuals leave the state of nature and enter into civil society, greed and corruption become more problematic, though his language is, as Laslett points out, "inexact" (Two Treatises, II, 111, n.). 
we have "given our human nature," or based on some sort of a priori notion of what humans are, but are a finely tuned set of obligations within a rationally structured universe. Applying one's labour to the land makes it more productive, allows more people to be fed, and thus fulfills both a scriptural and a natural law obligation. The command to labour is not, therefore, to allow unlimited accumulation without any moral constraints. Indeed, rather than seeing God's command to Adam to have dominion or even to labour "by the sweat of his brow" after his expulsion from Eden as a command to ceaseless toil and drudgery, Locke turns God's command into a duty which benefits the rest of humanity. ${ }^{38}$

The final stage in Locke's account of property concerns the invention of money. It is important to realize that, for Locke, money has no intrinsic value in and of itself, but is merely a sign that stands for the thing it purchases. ${ }^{39}$ One should note, too, that the value of money is arrived at through consent. Since it is arrived at through an agreement among individuals, it has no place in Locke's scheme of natural law; natural law, for Locke, quite simply cannot be arrived at through consent (see his unpublished Essays on the Law of Nature). While money is useful as a medium of exchange as it does not spoil, it is not natural but conventional, and therefore cannot be part of a natural rights claim to property. That money can be accumulated without violating the spoilage principle leads many to argue that Locke therefore allows for an unfettered accumulation of wealth within a national rights scheme. However, if we place Locke's account of rights within a theological framework, there are limits to the amount of money that one can accumulate and there are obligations put upon the use of money. One cannot claim that one has a natural right to accumulate vast riches beyond the subsistence level, even though this may, in practice, occur. For Locke vast accumulation cannot be based on a natural right; the accumulation of money is good only if it benefits humanity, helps feed the poor, and gives everyone the opportunity to enjoy the produce of the earth. Since money can facilitate exchange and avoid the spoilage principle, it can be seen as fulfilling the divine

38. Genesis, 1:28, 3:17.

39. Locke, II, 47. 
precepts of natural law if used wisely. Money, in principle at any rate, can be used to fulfill divine intentions.

For Locke, Jefferson, and the other framers of the Declaration of Independence, rights precede government, are there from the beginning, and are equally dispersed among the population. They are embodied in what Locke calls the "great blessing" of Genesis. ${ }^{40}$ Because all are united in Adam in the sense that all have reason and are capable of dominion, all are equal - no one has any more right than anyone else has. Even though humans may be different in terms of strengths, rationality, likes and dislikes, there is a fundamental unity in Adam that supersedes individual dissimilarities. Filmer's argument that differentiation among human beings is divinely decreed allows tyranny and slavery to operate on a vast scale, and gives no recourse for a change in regime. This Locke was not prepared to accept, and so it was necessary for him to attack the scriptural base to Filmer's argument, namely the early chapters of the book of Genesis. For Locke, God had not designated any one particular person the right to rule, but had given the earth and its creatures to all humanity, to use to preserve themselves and others. Thus, the fundamental right of self-preservation and the preservation of others forms the basis to Locke's theory of property. This right, however, has more in common with a divine obligation based on Scripture than with any notion of unfettered accumulation of wealth. And although we may have lost the biblical horizon on which to situate modern political discussion, our notion of what it means to live in a liberal democracy, complete with its "unalienable rights," would be vastly different without the theological framework of Locke's political philosophy.

40. Genesis, 1:28. 